\title{
Evaluation of the 2017 updated secondary school English curriculum of Turkey by means of theory-practice link
}

\author{
Erdem Aksoy \\ TED University, Faculty of Education, Ankara, Turkey, erdem.aksoy@ @ tedu.edu.tr
}

\begin{abstract}
This study evaluates the 2017 updated secondary school English curriculum of Turkey with the frame of Stake's (1967) congruence-contingency model. The study employed a mixed-methods research design. In this regard, triangulation was employed to provide data diversity. Four different data gathering tools were used: document analysis, interviews, structured questionnaires and in-class observations. The questionnaire data were gathered from 96 English language teachers, working in various cities of Turkey, and the interviews were conducted with seven English language teachers working at a public school in Ankara. In addition, classroom observations were conducted at four different classes in the same school. The findings of the study indicated that teachers considered the updated curriculum suitable and effective. However, in-class observations displayed that there are important gaps in bridging theory and practice. Thus, if there is a huge gap between what was intended and what was carried out, then first, an English as a foreign language education policy document should be prepared, and a unique foreign language-teaching ecosystem to include all stakeholders should be targeted.
\end{abstract}

Keywords: $\quad$ Curriculum evaluation, English language teaching, Foreign language policy, Teacher training

\section{Türkiye'de 2017'de güncellenen ortaokul İngilizce öğretim programının kuram-uygulama bağı kapsamında değerlendirilmesi}

ÖZ Bu araştırmada 2017 yılında güncellenen ortaokul İngilizce öğretim programlarının Stake'in (1967) uygunluk-olasılık modeli bağlamında değerlendirilmesi amaçlanmıştır. Araştırmada karma araştırma deseni benimsenmiştir ve bu bağlamda veri çeşitliliği sağlamak için üçgenleme tekniği kullanılmıştır. Araştırmada doküman analizi, görüşme, yapılandırılmış anket ve sınıf içi gözlemler şeklinde dört farklı veri toplama aracı kullanılmıştır. Anket verileri Türkiye'nin farklı illerinde çalışan 96 İngilizce öğretmeninden toplanmış, görüşmeler Ankara ilinde bir devlet ortaokulunda çalışmakta olan 7 İngilizce öğretmeni ile yapılmıştır. Diğer yandan, sınıf içi gözlemler aynı okulda dört farklı sınıf düzeyinde gerçekleştirilmiştir. Araştırma sonuçları öğretmenlerin güncellenen İngilizce öğretim programlarını uygun ve etkili bulduklarını göstermiştir. Ancak sınıf içi gözlemler, kuram-uygulama bağını sağlamada önemli problemler olduğunu göstermiştir. Bu nedenle hedeflenen ile uygulanan arasında önemli bir fark mevcut ise öncelikle yabancı dil olarak İngilizce dil eğitimi politika belgesi hazırlanması ve bu doğrultuda tüm paydaşları kapsayacak şekilde özgün bir yabancı dil öğretim ekosistemi amaçlanması gerekmektedir.

Anahtar Sözcükler:

Program değerlendirme, İnilizce öğretimi, Yabancı dil politikası, Öğretmen yetiştirme of theory-practice link. Turkish Journal of Education, 9(1), 1-21. DOI: 10.19128/turje.575392 


\section{INTRODUCTION}

In the globalized 21 st century, knowing a foreign language is the norm. Nowadays, education systems are expected to offer a second or even a third language. Individuals are increasingly expected to learn and use foreign languages in communicative environments. Similar to many other countries, primary and secondary school education in Turkey is focused on teaching and learning English as a foreign language (EFL) along with bettering language instruction.

Until 1997, the earliest that English was taught in Turkey was at secondary school. In 1997, with the introduction of the eight-year compulsory education, English was offered from the fourth grade. As a result of the changes in other countries, there emerged an interest in starting foreign language education at an earlier age. Compulsory education was extended from 8 to 12 years, as a result of the Law on Primary Education (Official Gazette, 2012). In this context, the $4+4+4$ system was introduced, and it was decided that foreign languages teaching should start in the second grade with two hours of instruction. Hence, a new foreign language curriculum was prepared and applied in the academic year of 2013-2014 by the Ministry of National Education (MoNE). In the curriculum, it was stated that the majority of students in Turkey were unable to use English as a language of communication and that was related to the status of the language as an academic requirement, rather than a communication tool. The curriculum was proposed to establish a relationship between the material used and the students' daily lives (MoNE, 2013).

The curriculum covers the objectives expected to be achieved by the students for each course, the gains representing the knowledge, skills and attitudes that are intended to be acquired by the students, in line with these objectives, and the explanation of the teaching and evaluation methods, techniques and strategies to be used in the process of transferring these to the students. The curriculum also covers the learning objectives that indicate the level of knowledge and skills that the students must achieve at each grade level. In this way, it guides the teachers and parents informing about what language knowledge and skills children are expected to acquire (MoNE, 2018). As Daloğlu (1996) stated, the most important issue to teach EFL is to establish a good curriculum with well-identified objectives. In particular, in the context of academic English, its success is only possible with a well-grounded curriculum.

\section{Curriculum Reform and English Language Teaching Curriculum Update}

All courses in the EFL curriculum for primary and secondary schools in Turkey were updated in 2017, and they were put into practice throughout the country in 2018. The MoNE based the curriculum update on considerations encompassing the following aspects: (MoNE, 2018): Research on skills that students must have in order to continue their education; Comparison and evaluation studies about curricula of countries with the best educational practices; National examinations; International examinations.

As a basis for the comprehensive curriculum development study, low scores from national-international examinations and the reasons behind meeting the expectations of higher education systems, together with the expectations of the market, have been put forward. It was further stated that international comparisons are used to analyze different education systems and to determine the ways of developing the Turkish education system based on these findings. For instance, one of the ways of analyzing educational systems was the comparison of the educational practices and curricula of different countries, based on the results of international evaluations. When the updated English curriculum was examined, an emphasis was given on the four fundamental language skills of listening, speaking, reading and writing (MoNE, 2018), as shown in Table 1. 
Table 1.

Fundamental points of the proposed curriculum

\begin{tabular}{|c|c|c|c|c|}
\hline $\begin{array}{c}\text { Levels } \\
\text { (CEFR) }\end{array}$ & $\begin{array}{c}\text { Hours/ } \\
\text { week }\end{array}$ & Grades & Skill focus & Main activities/strategies \\
\hline $\begin{array}{c}1 \\
(\mathrm{~A} 1)\end{array}$ & 2 hours & $\begin{array}{l}2 \\
3 \\
4\end{array}$ & $\begin{array}{l}\text { listening \& speaking } \\
\text { listening \& speaking } \\
\text { very limited reading \& writing } \\
\text { listening \& speaking } \\
\text { very limited reading \& writing }\end{array}$ & $\begin{array}{l}\text { TPR (Total physical response) / } \\
\text { Arts and Crafts/ Drama }\end{array}$ \\
\hline $\begin{array}{c}2 \\
(\mathrm{~A} 1)\end{array}$ & 3 hours & $\begin{array}{l}5 \\
6\end{array}$ & $\begin{array}{l}\text { listening \& speaking } \\
\text { limited reading } \\
\text { very limited writing } \\
\text { listening \& speaking } \\
\text { limited reading } \\
\text { limited writing }\end{array}$ & Drama / Role play \\
\hline $\begin{array}{c}3 \\
(\mathrm{~A} 2)\end{array}$ & 4 hours & $\begin{array}{l}7 \\
8\end{array}$ & $\begin{array}{l}\text { primary: listening \& speaking } \\
\text { secondary: reading \& writing } \\
\text { primary: listening \& speaking } \\
\text { secondary: reading \& writing }\end{array}$ & Theme-based \\
\hline
\end{tabular}

As can be seen in Table 1, the curriculum focuses on all four skills, and emphasis is given to listening and speaking in the second, third, and fourth grades. It can also be seen that in grades five to six, listening and speaking are emphasized and reading and writing are introduced at a limited level. Teaching methods, such as drama and role play, are emphasized. For grades seven to eight, the use of all four skills is encouraged with an emphasis on theme-based instruction. It is evident from the updated curriculum that it fosters the use of communicative language teaching (CLT) with a focus on values education.

Another salient feature of the curriculum is that the principles and descriptors of the Common European Framework of Reference for Languages: Learning, Teaching, Assessment (CEFR) are closely followed. The new curricular model emphasizes language use in an authentic communicative environment. As no single language teaching methodology is seen as flexible enough to meet the needs of learners at various stages and to address a wide range of learning styles, an eclectic mix of instructional techniques has been adopted, drawing on an action oriented approach in order to allow learners to experience English as a means of communication, rather than focusing on the language as a topic of study (MoNE, 2018, p.3). In addition, in order to impress on students, the role of English as a means of relaying needs and wants, voicing opinions and beliefs, building relationships, and so on, the new curricular model focuses on language learning as communication. In other words, learners/users engage in activities which require actual communication between peers or between students and their teacher, such as creating a game as a group and then playing it with classmates, rather than rehearsing prepared material (p.4).

\section{Curriculum Evaluation}

Systematic and continuous evaluation of any curriculum and identification of the strengths and weaknesses is extremely important for the effective teaching of English. In addition, systematic curriculum evaluation will provide a better implementation of curricula and provide guidance to teachers and students. In this regard, the evaluation process may be defined as the process of collecting, editing and fine-tuning the data (Ornstein \& Hunkins, 2016). According to Varış (1997), curriculum evaluation has an important and permanent place in its development. Since the process requires teamwork, group working techniques and coordination are included. Assumptions are made for the training of qualified students and in-class (inside and outside school) activities are compared; specific method trials are attempted, and the richness of the methods is highlighted. Processes and results are evaluated continuously and shaped according to the feedback; new assumptions are tried out to develop one or more of the structural elements. Thereby, the continuity of curriculum development is ensured. A continuous assessment process is required to observe the implementation of the new curricula. As 
Gözütok (2001) and Ültanır (2003) suggested, questioning and evaluating the implementation of the prior curricula is the starting point for curriculum development.

The extent to which the competences targeted by an updated curriculum on paper are reflected in realized implementation is extremely important, in terms of strengthening the theory-practice link and shedding light on the work to develop the curriculum. Many studies show that curriculum updates carried out under the name of reform are not reflected in the implementation and remain limited to being on paper (Cheserek \& Mugalavi, 2012; Wang, 2006). EFL curriculums of countries where English is taught as a foreign language show that curriculum change is seldom transferred to real class implementations (Hamid \& Honan, 2012; Yaacob, 2006). However, as Varış (1997) stated, in curriculum development, evaluation should keep an important and permanent place. Processes and results should be evaluated continuously, and new assumptions should develop one or more of the structural elements, according to the feedback received. Thus, this will ensure the continuity of the curriculum development mechanism.

Studies on the evaluation of previous English teaching curricula, in Turkey, usually focused on teachers' opinions and perceptions (Büyükduman, 2005; Demirlier, 2010; Er, 2006; Erbakan, 2001; Erbilen Sak, 2008; Erdoğan, 2005; Kandemir, 2016; Dinçer \& Saracaloğlu, 2018). However, studies that focused on the alignment between policy and practice in the Turkish context were extremely limited (such as Dinçer, 2013). In one salient study, Yücel, Dimici, Yıldız and Bümen (2017) analyzed the implementation of English language curricula published over the last 15 years. They found out that the communicative approach was adopted in secondary school curricula but could not be practiced as suggested by other studies and that in the 2011 secondary school program the interests and needs of the students were ignored in content and objective design. In addition, as the updated English curriculum was first implemented in 2018, very few studies in the literature were observed to be evaluating the updated version. A study by Yüce (2018) tried to find out the compatibility of the secondary education ninth grade updated English language teaching program, to the principles of the CEFR. The results showed that the outcomes of the 9th grade English language teaching program were not completely compatible with the proficiency descriptors of the CEFR, and issues such as course materials, course hours, self-assessment and in-service training activities for the teachers, affected the implementation of the program negatively. However, the activities of the EFL program were appropriate for and suited to the students' language levels and ages. In another study, Erdem and Yücel Toy (2017) wanted to determine the needs for the foreign language oriented 5th grade English curriculum. According to the findings of their study, the problems most frequently encountered by English teachers of the foreign language oriented 5th grades were the size of the classes, the lack of a prepared curriculum for 20162017 academic year and the lack of a course book. Finally, Ağçam and Babanoğlu (2018) compared the primary school and secondary school English curricula of 2017 through an analysis of the intended learning outcomes and found out that primary school English course objectives were extensively designed to address students' lower- rather than higher-order cognitive skills. The current study, expanding the findings in the previous research, was designed to find out if there is such a gap between theory and practice; in other words, to evaluate the updated secondary school English curriculum of Turkey, based on Stake's evaluation model of congruence-contingency.

\section{Stake's Congruence-Contingency Model}

According to Stake (1967), in order to evaluate, an educator needs to gather certain data, and these data are likely to be from several different sources. The purpose might be description or judgment, but in each case, three bodies of information should be tapped into. In the evaluation report, it can be helpful to distinguish between antecedents, transactions and outcomes data.

According to Stake (1967), there are two principal ways of processing descriptive evaluation data: finding the contingencies among antecedents, transactions, and outcomes and finding the congruence between "intents" and "observations". The data for a curriculum are congruent if what was intended actually happens. The model is shown in Figure 1. 


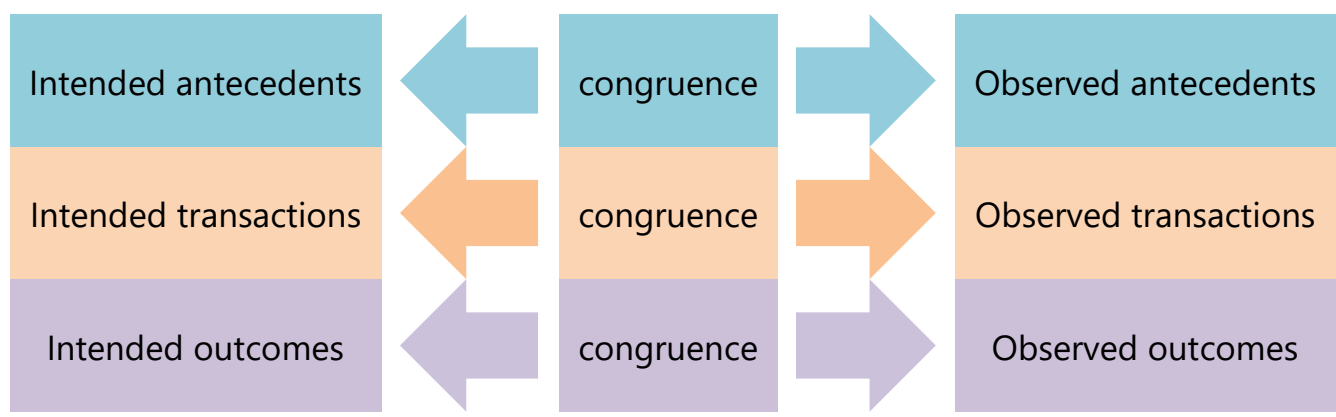

Figure 1. Stake's congruence-contingency model

Stake's model is useful for demonstrating the realization level of the features and targets expected in a curriculum. Therefore, Stake's congruence-contingency model was adopted within the scope of the present research. It considers all three levels of congruence and contingency as intended and observed antecedents, transactions and outcomes. Antecedents is about the readiness and introductory statuses of the students and the learning environment. Thus, antecedents are not the focus of this study. Similarly, since outcomes refer to the degree of student learning or success, they were also not targeted in this research. Instead, this study targeted on congruence and contingency among the intended and observed transactions. In this context, the 2017 updated secondary school English language curriculum in Turkey, put into practice in 2018, was examined through the secondary school English teachers' opinions and classroom observations. The reason for considering the secondary school level in the research was that different expectations for grades five to six and seven to eight can be observed in the curriculum structure. While drama/role-play techniques were proposed for grades five to six, a theme-based structure was proposed for grades seven to eight. On the other hand, for the former, limited reading and very limited writing was suggested; however, for the latter grades, teaching all the skills with a themebased approach was suggested. For these reasons, the evaluation of the secondary school English curriculum was considered to be salient.

\section{Research Objectives}

The primary aim of this study was to evaluate the updated secondary school English language curriculum, in terms of intended and observed transactions, to examine the alignment between policy and practice.

The research questions of the study are:

How do teachers perceive the updated curriculum regarding its objectives, content, generation of learning experiences and assessment?

How is the updated English curriculum implemented in classrooms?

\section{METHODOLOGY}

The present study employs a mixed-methods research design. This study is an instrumental case study aiming at providing information on EFL teaching in the context of secondary education in Turkey and, consequently, making suggestions to address identified problems by examining the case of a secondary school in Ankara. The researcher is interested in studying the particular case, only as a means to some larger goal (Fraenkel, Wallen \& Hyun, 2012). As data gathering tools, documents, interview form, questionnaire and in-class observation form were utilized. The different data collection tools allowed triangulation in order to enhance the reliability of results. The data from multiple sources were analyzed 
together. The reason behind the triangulation was that the strengths of the various data gathering tools would complement each other and offset each method's respective weaknesses. (Fraenkel, Wallen \& Hyun, 2012).

\section{Participants and Sampling}

For the online questionnaire, the snowballing sampling method was considered, through which all voluntary participants in various provinces of Turkey were targeted. For the interviews and observations, one public secondary school in Ankara employing intensive English language teaching was chosen. This was believed to be a suitable school with mostly experienced English language teachers (minimum 15 years of experience) and students from various socio-economic backgrounds. The selected school is an urban school, and it employs an English intensive education at the fifth-grade level. Demographic information on the teachers responding to the online questionnaire is given in Table 2.

Table 2.

Participants in the online questionnaire

\begin{tabular}{llll}
\hline Variable & Category & f & $\%$ \\
\hline \multirow{2}{*}{ Gender } & Male & 21 & 22 \\
& Female & 75 & 78 \\
Age & $0-25$ & 15 & 16 \\
& $26-40$ & 63 & 66 \\
\multirow{2}{*}{ Type of school } & $41-50$ & 14 & 15 \\
& 51 and above & 4 & 3 \\
Undergraduate department & Public & 92 & 96 \\
\multirow{2}{*}{ Graduate degree } & Private & 4 & 4 \\
& English language teaching & 79 & 82 \\
\multirow{3}{*}{ Experience } & Others & 17 & 18 \\
& Yes & 2 & 2 \\
\multirow{2}{*}{ Knowledge about the new curriculum document } & No & 94 & 98 \\
& $0-5$ & 42 & 44 \\
& $6-10$ & 27 & 28 \\
& $11-15$ & 9 & 9 \\
& 16 and more & 18 & 19 \\
& Yes & 73 & 76 \\
& Partly & 23 & 24 \\
\hline
\end{tabular}

An overview displaying demographic data of the participants in the interviews is shown in Table 3.

Table 3.

Participants in the interviews

\begin{tabular}{llcc}
\hline \multicolumn{1}{c}{ Variable } & \multicolumn{1}{c}{ Category } & f & $\%$ \\
\hline Gender & Male & 1 & 14 \\
\multirow{3}{*}{ Age } & Female & 6 & 86 \\
& $0-25$ & 1 & 14 \\
& $26-40$ & 4 & 57 \\
\multirow{4}{*}{ Undergraduate curriculum type } & $41-50$ & 2 & 29 \\
\multirow{2}{*}{ Graduate degree } & 51 and above & & \\
\multirow{3}{*}{ Experience } & English language teaching & 4 & 57 \\
& Others & 3 & 43 \\
& Yes & 7 & 100 \\
& No & - & - \\
Attendance to in-service training & $0-5$ & & \\
& $6-10$ & - & - \\
& $11-15$ & - & - \\
& 16 and more & 7 & 100 \\
& Yes & 1 & 14 \\
& No & 6 & 86 \\
\hline
\end{tabular}

Participants for the interviews comprised seven English language teachers working at a public elementary school all with a minimum 15 years of teaching experience. None of them had a graduate 
degree and the majority had not attended any kind of in-service training. As shown in Table 3, most of the interviewees were aged between 41 and 50 and they were all above 26 years of age.

\section{Data Collection Tools}

As data collection tools, a semi-structured interview form, classroom observation forms and a structured online questionnaire were employed; additionally, documents were analyzed. Data collected from the documents, interviews, and questionnaires were used to make inferences about the theory-practice link, by establishing connections with data gathered from the in-class observations.

\section{Document Analysis}

For this study, the 2017-updated curriculum document of MoNE acted as the main document as well as the course books and supplementary materials/resources delivered by MoNE. Sample lesson plans of the observed teachers and the electronic tools they used also acted as documents. The document analyses provided the grounds for the online questionnaire, semi structured interview form, and in-class observation form: The documents provided by MoNE entailed the components that needed to be considered in the actual instructional practice as evidence if the curricular changes had been implemented sufficiently.

\section{Structured Online Questionnaire}

A structured questionnaire consisting of two sections was designed, informed by the updated English curriculum. The first section collected demographic data while the second section elicited the teachers' opinions about various dimensions of the updated curriculum. The questions within each section of the questionnaire were formed based on the main components and expectations stated in the curriculum. All questions were first, categorically defined as "yes", "no", and "partly", and the participants were then asked to write about their opinions. Thus, detailed responses of the participants were targeted. The draft questionnaires were then sent to three academics in the field of English language teaching, to check for the suitability of the questions. The questions were fine-tuned, based on the suggestions of the experts, and the questionnaire was then piloted with five English language teachers working in Ankara. The suggested fine tunings were employed, based on the opinions of these teachers, and the questionnaire was finalized. There are nine items in the first section, ten items about the objectives of the curriculum, 13 items about the content, eight items about the learning experiences, eight items about evaluation, and 22 items about the implementation process.

\section{Semi-structured Interviews}

Interviews with seven English language teachers were conducted in a public secondary school in Ankara. Although the school is an urban school, in the heart of Ankara, various students from the nearby rural districts attend this school. The reason behind the selection of this school was that all the English language teachers were experienced in teaching English to secondary school level students, and that the school utilized an English-language intensive education for especially, the fifth-grade level. A semistructured interview form consisting of 11 questions was composed, based on the information gathered through document analyses. Interview questions were first sent to three experts in the field of English language teaching to examine for suitability, and the necessary fine tuning was made based on the feedback gathered from these experts. Subsequently, the interview questions were piloted with two English language teachers working at a secondary school in Ankara. As a result, the questions were finalized. Interviews were conducted with seven English language teachers at the selected secondary school in May 2019. All interviews were tape-recorded with the permission of the participants and then transcribed. Each interview lasted around 30 minutes. Interviews were conducted in Turkish, as it is the native language of all the participants. 


\section{Classroom Observations}

Classroom observations were carried out to reveal the alignment between policy and practice (Carless, 2004). An observation form consisting of 20 items was developed based on the key indicators of the updated secondary school English curriculum. The form was sent to three English language teaching academics to check for the suitability of the statements. The items were categorically defined as "yes", "no", and "partly", and an open-ended section was added next to each item for further comments and details. Thus, the form served both as a checklist defining key dimensions, as suggested in the curriculum, as well as a detailed form to gather comments on each item. One-hour classroom observations were carried out at each classroom level (grades five to six and seven to eight). The aim of the observation form was to figure out if there was a gap between theory-practice link in terms of the intended and observed curriculum implementation. Thus, the form consisted of items that the updated curriculum required such as the implicit use of grammar in classes and the researcher checked whether each requirement was fulfilled in different classes. The same observation form was used at all grades. The observer identified himself as a researcher but stuck to non-participant observation as he did not interfere in classroom practice.

\section{Data Collection Procedures}

Data were collected over a two-month period. First, documents were collected and analyzed to examine the updated curriculum and to develop the data collection tools, then the online questionnaire was sent to English language teachers working in various cities of Turkey. Interviews with teachers were conducted in May 2019. Classroom observations were then carried out to determine the alignment between intended and observed transactions of the curriculum. The observations were carried out in four different EFL classrooms. Each class was observed once, and each observation lasted for one hour; a total of four lessons were observed.

\section{Data Analysis}

Data regarding the online questionnaire were analyzed by means of descriptive statistics. Data from the interviews were analyzed using content analysis. Teachers' answers to the interview questions were first transcribed and sent back to the participants for clarification. Then they were analyzed using the NVivo software. As for the coding process, a pattern-coding method was used (Miles \& Huberman, 1994). Consent was obtained from the TED University Ethical Committee for the suitability of the study in terms of ethical codes and guidelines, No: 27535802-020/, Date: 09.05.2019. Further consent was gathered from the Provincial Directorate of National Education-Ankara, No: 14588481-605.99E.7723497, Date: 16.04.2019. Data regarding classroom observations were analyzed through frequency analyses.

\section{FINDINGS}

In the following sections, the findings are reported for the structured online questionnaire, the semistructured interviews, and the classroom observations separately. For the questionnaire, the teachers' views on the dimensions examined (curriculum objectives, content, teaching-learning process, assessment and implementation process) serve as guiding principles to present the findings. The results for the interviews are reported in terms of perceived strengths and weaknesses. The results concerning classroom observations focus on to what extent curricular requirements were considered in actual instructional practice. 


\section{Findings Regarding the Structured Online Questionnaire}

The analysis of the questionnaire was carried out with data gathered from 96 English language teachers, and descriptive statistics (percentages) were used to analyze the quantitative data.

\section{Opinions of English language teachers on the suitability of objectives}

The opinions of English language teachers on the suitability of the objectives of the updated secondary school curriculum are presented in Table 4. The most striking and the highest gained value is that most of the teachers agreed that the program aims to use English for communication purposes, rather than focusing on language structures only. On the other hand, approximately half of them agreed that, with the lowest gained value, the objectives of the program could be reached by the students under the current circumstances. On the whole, the majority of the teachers regarded the objectives of the updated curriculum as suitable and effective.

Table 4.

Opinions of English language teachers regarding the suitability of objectives

\begin{tabular}{|c|c|c|c|c|c|c|}
\hline Variables & Yes & $\%$ & Partly & $\%$ & No & $\%$ \\
\hline The program aims to use English in an authentic and communicative environment. & 65 & 68 & 28 & 29 & 3 & 3 \\
\hline $\begin{array}{l}\text { The program aims to use English for communication purposes rather than language } \\
\text { structures. }\end{array}$ & 79 & 82 & 13 & 14 & 4 & 4 \\
\hline Objectives highlight the use of values such as friendship and justice. & 63 & 66 & 26 & 27 & 7 & 7 \\
\hline $\begin{array}{l}\text { Objectives highlight the use of key competences such as communication, and digital } \\
\text { skills. }\end{array}$ & 67 & 70 & 24 & 25 & 5 & 5 \\
\hline Obje & 59 & 62 & 26 & 27 & 11 & 12 \\
\hline Obje & 72 & 75 & 19 & 20 & 5 & 5 \\
\hline $\begin{array}{l}\text { vely by taking into account main } \\
\text { ive. }\end{array}$ & 70 & 73 & 23 & 24 & 3 & 3 \\
\hline geted to improve affective skills of students as well as cognitive skills. & 78 & 81 & 15 & 16 & 3 & 3 \\
\hline $\begin{array}{l}\text { g and fun through its } \\
\text { s. }\end{array}$ & 68 & 71 & 21 & 22 & 7 & 7 \\
\hline $\begin{array}{l}\text { I believe that objectives of the program can be reached by students under current } \\
\text { circumstances. }\end{array}$ & 54 & 56 & 30 & 31 & 12 & 13 \\
\hline
\end{tabular}

\section{Opinions of English language teachers on the suitability of content}

Opinions of the English language teachers on the suitability of content of the updated secondary school curriculum are presented in Table 5.

Table 5 .

Opinions of English language teachers regarding the suitability of content

\begin{tabular}{|c|c|c|c|c|c|c|}
\hline Variable & Yes & $\%$ & Partly & $\%$ & No & $\%$ \\
\hline The program covers authentic materials to stress the communicative perspective. & 59 & 62 & 30 & 31 & 7 & 7 \\
\hline The program provides materials as learning tasks for task-based learning. & 67 & 70 & 24 & 25 & 5 & 5 \\
\hline $\begin{array}{l}\text { The program provides materials and learning sources derived from authentic } \\
\text { sources. }\end{array}$ & 53 & 55 & 26 & 27 & 17 & 17 \\
\hline $\begin{array}{l}\text { The program provides suitable, interesting and achievable learning contexts for both } \\
\text { teachers and book writers. }\end{array}$ & 53 & 55 & 29 & 30 & 14 & 15 \\
\hline The program leads teachers to prepare materials covering values. & 57 & 59 & 26 & 27 & 13 & 14 \\
\hline $\begin{array}{l}\text { Values such as friendship and justice are interwoven in each unit and theme of the } \\
\text { curriculum. }\end{array}$ & 59 & 62 & 27 & 28 & 10 & 10 \\
\hline The program provides samples of activities to cover values and ethical principles. & 66 & 69 & 22 & 23 & 8 & 8 \\
\hline $\begin{array}{l}\text { Structures and linguistic functions are implicitly provided for the authentic use of } \\
\text { the language. }\end{array}$ & 78 & 81 & 16 & 17 & 2 & 2 \\
\hline The content stresses the development and appreciation for students' unique culture & 71 & 74 & 20 & 21 & 5 & 5 \\
\hline $\begin{array}{l}\text { The content stresses the value of home culture in order to avoid the formation of } \\
\text { negative attitudes. }\end{array}$ & 70 & 73 & 22 & 23 & 4 & 4 \\
\hline The & 78 & 81 & 13 & 14 & $J$ & 5 \\
\hline The content exemplifies characters and places that learners are likely to encounter. & 71 & 74 & 20 & 21 & 5 & 5 \\
\hline $\begin{array}{l}\text { I believe that contents of the program are suitable for students under current } \\
\text { circumstances. }\end{array}$ & 46 & 48 & 31 & 32 & 19 & 20 \\
\hline
\end{tabular}


The most striking and the highest gained values are that most of the teachers agreed that structures and linguistic functions are implicitly provided for the authentic use of the language in an interactive context, rather than as a separate entity, and the content for the seventh and eighth grades were organized as themes. On the other hand, less than half of the teachers agreed that, with the lowest gained value, contents of the program are suitable for students under the current circumstances. It could be observed that the majority of teachers regarded the contents of the updated curriculum as suitable and effective.

\section{Opinions of English language teachers on the suitability of teaching-learning process}

The opinions of the English language teachers on the suitability of teaching-learning process of the updated secondary school curriculum are presented in Table 6 .

Table 6.

Opinions of English language teachers regarding the suitability of the teaching-learning process

\begin{tabular}{|c|c|c|c|c|c|c|}
\hline Variable & Yes & $\%$ & Partly & $\%$ & No & $\%$ \\
\hline $\begin{array}{l}\text { The program stresses English as the medium of instruction in class to improve } \\
\text { communicative competence. }\end{array}$ & 79 & 82 & 13 & 14 & 4 & 4 \\
\hline The program provides activities such as game play. & 67 & 70 & 24 & 25 & 5 & 5 \\
\hline The program offers various teaching methods and techniques to stress the values. & 62 & 65 & 24 & 25 & 10 & 10 \\
\hline $\begin{array}{l}\text { The program takes and exemplifies teaching-learning and assessment processes as a } \\
\text { whole to diversify teaching techniques of teachers as well as learning strategies of } \\
\text { students. }\end{array}$ & 71 & 74 & 22 & 23 & 3 & 3 \\
\hline ram stresses techniques such as drama and role-play in 5th and 6th grades. & 64 & 67 & 28 & 29 & 4 & 4 \\
\hline Activ & 64 & 67 & 30 & 31 & 2 & 2 \\
\hline Reading and writing skills are adequately addressed in 7 th and 8th grades. & 68 & 71 & 26 & 27 & 2 & 2 \\
\hline $\begin{array}{l}\text { I believe that teaching-learning process of the program is suitable for students under } \\
\text { current circumstances. }\end{array}$ & 64 & 67 & 23 & 24 & 9 & 9 \\
\hline
\end{tabular}

A large majority of the teachers agreed that the program stresses on English as the medium of instruction in class to improve communicative competence. Showing the lowest level of agreement in the dimension teaching-learning process, more than half of the teachers agreed that the program offers various teaching methods and techniques to stress on values. As all the variables are over $50 \%$, it can be said that majority of the teachers regarded the teaching-learning process of the updated curriculum as suitable and effective.

\section{Opinions of English language teachers on the suitability of assessment}

The opinions of the English language teachers on the suitability of the assessment process of the updated secondary school curriculum are presented in Table 7.

Table 7.

Opinions of English language teachers regarding the suitability of assessment process

\begin{tabular}{|c|c|c|c|c|c|c|}
\hline Variable & Yes & $\%$ & Partly & $\%$ & No & $\%$ \\
\hline $\begin{array}{l}\text { Assessment procedures of each unit exemplify samples as to what is expected from } \\
\text { the teachers. }\end{array}$ & 69 & 72 & 20 & 21 & 7 & 7 \\
\hline Assessment samples create positive washback. & 69 & 72 & 20 & 21 & 7 & 7 \\
\hline Assessment is mainly based on alternative and process-oriented techniques. & 67 & 70 & 21 & 22 & 8 & 8 \\
\hline The program provides samples of self-assessment. & 76 & 79 & 15 & 16 & 5 & 5 \\
\hline The program provides samples of checklists for self-assessment. & 79 & 82 & 13 & 14 & 4 & 4 \\
\hline $\begin{array}{l}\text { Both process and product-oriented assessment techniques are used to measure } \\
\text { students' communicative competence. }\end{array}$ & 67 & 70 & 23 & 24 & 6 & 6 \\
\hline $\begin{array}{l}\text { Various assessment techniques are exemplified to support students with their own } \\
\text { pace of learning in and out of class. }\end{array}$ & 49 & 51 & 35 & 37 & 12 & 13 \\
\hline $\begin{array}{l}\text { I believe that assessment process of the program is suitable for students under } \\
\text { current circumstances. }\end{array}$ & 57 & 59 & 31 & 32 & 8 & 8 \\
\hline
\end{tabular}

The most striking and the highest gained value is that most of teachers agreed that the program provides samples of checklists for self-assessment. On the other hand, half of them, with the lowest gained value, agreed that various assessment techniques are exemplified to support students with their own pace of 
learning, in and out of class. As all the variables are over $50 \%$, it can be said that the majority of teachers regarded the assessment process of the updated curriculum as suitable and effective.

\section{Opinions of English language teachers regarding the implementation process}

The opinions of the English language teachers regarding the implementation process of the updated secondary school curriculum are presented in Table 8.

Table 8 .

Opinions of English language teachers regarding the implementation process

\begin{tabular}{|c|c|c|c|c|c|c|}
\hline Variable & Yes & $\%$ & Partly & $\%$ & No & $\%$ \\
\hline $\begin{array}{l}\text { The materials that I use in class cover the key competences stressed in the } \\
\text { curriculum. }\end{array}$ & 64 & 67 & 30 & 31 & 2 & 2 \\
\hline I can align values with the activities that I use in class. & 73 & 76 & 19 & 20 & 4 & 4 \\
\hline $\begin{array}{l}\text { I can focus on strengthening the communication in class rather than trying to rush } \\
\text { over to cover the topics of the curriculum. }\end{array}$ & 48 & 50 & 30 & 31 & 18 & 19 \\
\hline $\begin{array}{l}\text { Students in my classes can listen and speak as if they were in an authentic } \\
\text { environment. }\end{array}$ & 46 & 48 & 37 & 39 & 13 & 14 \\
\hline The communication in my classes is in English as much as possible. & 51 & 53 & 39 & 41 & 6 & 6.3 \\
\hline The communication process in my classes is for creation of meaning. & 84 & 88 & 10 & 10 & 2 & 2 \\
\hline $\begin{array}{l}\text { I use the structural and linguistic elements of the language implicitly to create } \\
\text { meaning rather than focusing on them as separate topics. }\end{array}$ & 69 & 72 & 22 & 23 & 5 & 5 \\
\hline I can adequately focus on cultural elem & 68 & 71 & 25 & 26 & 3 & 3 \\
\hline I can & 73 & 76 & 20 & 21 & 3 & 3 \\
\hline I can lead students to use various learning & 83 & 87 & 12 & 13 & 1 & 1 \\
\hline $\begin{array}{l}\text { My students can transfer their knowledge and skills of English into every phase of } \\
\text { learning process. }\end{array}$ & 54 & 56 & 36 & 38 & 6 & 6 \\
\hline $\begin{array}{l}\text { I provide materials to my students so that they can reinforce what they already } \\
\text { know. }\end{array}$ & 83 & 87 & 12 & 13 & 1 & 1 \\
\hline My students can create materials to share with other classes and students. & 64 & 67 & 26 & 27 & 6 & 6 \\
\hline $\begin{array}{l}\text { My students can learn English by creating with language rather than learning about } \\
\text { the language. }\end{array}$ & 57 & 59 & 33 & 34 & 6 & 6 \\
\hline $\begin{array}{l}\text { I can get adequate in-service training during the implementation of the updated } \\
\text { curriculum. }\end{array}$ & 37 & 39 & 25 & 26 & 34 & 35 \\
\hline $\begin{array}{l}\text { I focus on listening and speaking skills with } 5 \text { th and } 6 \text { th graders rather than reading } \\
\text { and writing. }\end{array}$ & 47 & 49 & 29 & 30 & 20 & 21 \\
\hline I adequately focus on reading and writing skills with 7 th and 8 th graders. & 79 & 82 & 13 & 14 & 4 & 4 \\
\hline $\begin{array}{l}\text { I believe that such techniques as drama and role-play are effective for } 5 \text { th and } 6 \text { th } \\
\text { graders. }\end{array}$ & 83 & 87 & 11 & 12 & 2 & 2 \\
\hline $\begin{array}{l}\text { I can align different courses in the frame of the Thematic approach with } 7 \text { th and 8th } \\
\text { graders. }\end{array}$ & 74 & 77 & 21 & 22 & 1 & 1 \\
\hline $\begin{array}{l}\text { I use alternative assessment techniques such as self and peer assessment rather than } \\
\text { product-oriented techniques such as written test or quiz. }\end{array}$ & 48 & 50 & 25 & 26 & 23 & 24 \\
\hline $\begin{array}{l}\text { I develop and use materials derived from authentic sources to improve the } \\
\text { communication process. }\end{array}$ & 75 & 78 & 18 & 19 & 3 & 3 \\
\hline $\begin{array}{l}\text { I can adequately implement the updated curriculum in my classes under current } \\
\text { circumstances. }\end{array}$ & 63 & 66 & 32 & 33 & 1 & 1 \\
\hline
\end{tabular}

The most striking and the highest gained values are that most of the teachers stated that the communication process in their classes was to create meaning, and that they could direct students to various learning strategies. On the other hand, few of them agreed that they could get adequate in-service training during the implementation of the updated curriculum; students in their classes could listen and speak as if they were in an authentic environment; they focused on listening and speaking skills with the fifth and sixth graders rather than reading and writing. As there are only three variables below $50 \%$, it can be said that the majority of the teachers regarded the implementation process of the updated curriculum as suitable and effective.

\section{Interviews with English Language Teachers}

The answers of the seven English language teachers interviewed were analyzed using content analysis and presented under "positive opinions" and "opinions regarding the suggested improvements" 


\section{Positive opinions regarding the updated curriculum and its implementation}

Figure 2 visualizes the positive responses of the teachers interviewed. The values provided in the parentheses represent the frequencies of opinions. Similarly, the thickness of the arrows represents the relative density of opinions. The best part of the curriculum, according to the teachers, is that it focusses heavily on the communicative approach, is based on thematic instruction, fosters technological support and EBA (education information technologies network) platforms, and that it is suitable for foreign language intensive secondary schools.

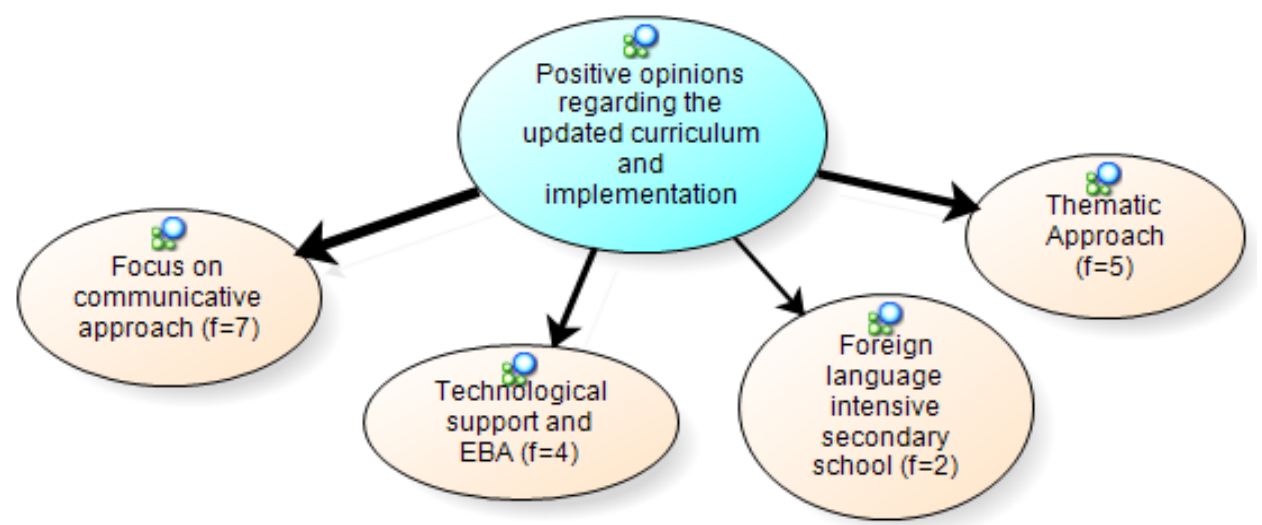

Figure 2. Findings regarding the positive aspects of the curriculum and its implementation

The communicative approach of the curriculum was regarded positive as evidenced in the following quote: "The updated program helped us improve the learning process. We do not look for another approach as I believe that our students are learning English effectively by communicating with each other". (T1) The thematic approach was appreciated as it was believed to be useful to align various topics". (T3) Also, the curriculum's strength as addressing the needs of foreign language intensive secondary schools was emphasized: "Interactive teaching methods can be applied to foreign language intensive classes. In other classes, on the other hand, this is not possible" (T5).

\section{Opinions regarding the suggested improvements}

When the opinions of the English language teachers regarding the suggested improvements were analyzed, it was observed that they stressed eight main points, which are presented in Figure 3.

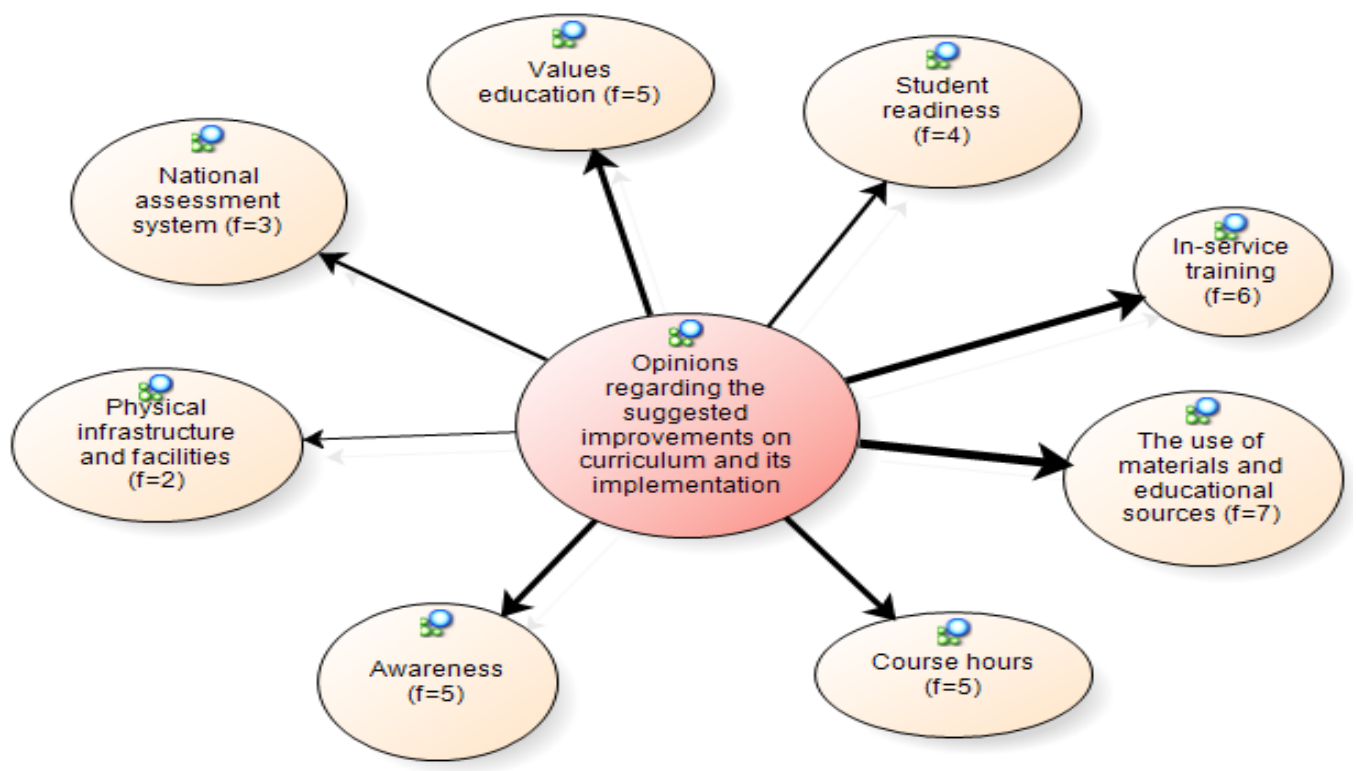

Figure 3. Findings regarding the suggested improvements on the curriculum and its implementation 
The most salient weaknesses of the curriculum and, thus, areas of suggested improvement were that it lacked adequate support in terms of materials and educational sources. As one teacher puts it: "Limitations on the use of classroom materials are leading us into trouble. Compulsory books provided by the MoNE are insufficient. We always have to upgrade the content" (T1).

Another weakness of the curriculum was stated as the inadequacy of in-service training. One teacher said: "Teachers should take in-service trainings through which they will upgrade their knowledge and understanding of contemporary teaching methodologies" (T5). One notable suggestion showed the insufficient course hours stating that "I don't have enough time to realize communicative activities and improve my learners' communicative skills. Time is the most important problem as we have lots of objectives to cover in a very limited amount of time" (T1). Awareness, on the other hand, was said to be another weakness of the curriculum and thus an area of concern for the betterment. As one teacher remarked "In my opinion, the biggest problem is that students do not understand the necessity of learning English. Families also create a negative impact." The most frequent statement we hear is "Teacher! Why do we learn English? Let them learn Turkish" (T6). Values education, which was heavily emphasized in the updated curricula, represents another area of weakness that needs to be strengthened according to the participants. As one teacher emphasized "In my opinion, these values should be taught together with international values such as peace. In addition, students should have already started learning about these values in kindergarten. If not covered at earlier stages, values have no use other than appearing on bulletin boards. And I believe that they cannot be incorporated into English lessons" (T2).

\section{In Class Observations}

A structured observation form examining if main components of the curriculum were considered in actual classroom teaching was used to analyze lessons. The observation aimed at indicating if the upgraded curriculum was sufficiently implemented in realized classroom practice by indicating if dimensions were incorporated fully, partly or were not integrated. Findings of the observation form are presented in Table 9 (Appendix 1).

As seen in Table 9, lack of incorporation of dimensions requested in the curriculum prevails for all class levels and various variables inspected. While the density is lower at the sixth grade, in grades 5, 7 and 8 , it is clear that the alternative "no" dominates the whole observation scale. It became evident that at all four class levels, activities and values were not adequately aligned. In addition, structural and linguistic elements of the language were addressed as separate topics, and values such as friendship, justice, honesty, self-control, patience, etc. were inadequately addressed. Furthermore, students were not led to use various learning strategies, and they could not transfer their knowledge of English into different contexts. Finally, product-oriented assessment techniques such as tests and written quizzes were emphasized. At three class levels (fifth, seventh and eighth grades), it was observed that in-class materials did not cover key competences and values stressed in the curriculum, and class time was mostly used to cover topics stated in the curriculum rather than strengthening communication. In addition, students were not given opportunities to listen or speak by generating language practice resembling authentic contexts, and they learned about the language rather than doing something with it. Materials were not developed from authentic sources, and the implementation of the curriculum was not adequately actualized. On the other hand, at one class level (sixth grade), communication was completely conducted in English, and for two other levels (seventh and eighth grade), it was partly conducted in English. However, this communication was one sided-from the teacher to the students.

At two class levels (sixth and eighth grades), it was observed that cultural elements were partly incorporated into classes. On the other hand, at the fifth and sixth grade levels, listening and speaking skills were addressed; however, techniques such as drama and role-play were not adequately used. At the seventh and eighth grade levels, it was observed that alignment among the various courses by means of the thematic approach was unsuccessful, and reading and writing skills were partly used. Finally, a positive aspect that was observed for all class levels was that the students were provided with materials to strengthen their prior learnings. 


\section{DISCUSSION}

Employing Stake's (1967) congruence-contingency model, it was found out in the present study that the updated secondary school EFL curriculum and its implementation by English language teachers lacked consistency and congruence, in terms of intended and observed transactions. As a result of the questionnaire, it was found that teachers mostly held positive opinions on aims, content, learning experiences, evaluations and implementation dimensions of the updated secondary school English curriculum. Teachers welcomed that the curriculum emphasized communicative competence and that it focused on cultural elements as well as values. Teachers also welcomed interactive teaching methods and alternative assessment techniques. Interview results support the findings obtained from the questionnaire. Teachers who were interviewed stated that with the help of the updated curriculum, the communicative process could be further emphasized in classes, and they supported the use of themebased instruction. The questionnaires and interview findings also indicated that teachers supported and tried to use the communicative approach in their classes. However, classroom observations revealed that in-class activities and implementations were not compatible with the demands of the communicative approach.

Findings of the present study are supported by previous studies. As Kirkgöz (2008) observed, teachers do not necessarily internalize and implement activities based on the communicative approach, and students do not actively participate in classes, particularly when they are teacher driven. In the present study, it was also found that communicative activities could not be successfully reflected in classroom practices; rather, they were based on knowledge transfer and structural elements of the language. These findings overlap with the findings of Coşkun (2011), who detected discrepancy between intended and realized classroom practices due to large class sizes, traditional grammar-based assessment and insufficient time to prepare communicative materials. Findings also support the study of Denkci Akkaş and Coker (2016) who found out that English language teaching at the high school level in Turkey does not reflect the communicative language classroom depicted in the text of the national curriculum. Echoing Karavas (1993), it is worth noting that the communicative approach is observed at the theory level rather than in-class implementations. In this context, key competences in the curriculum were seldom reflected in class activities. As Kırkgöz, Çelik and Arıkan stated (2016), it is important to note that, even with the existence of a viable curriculum, successful implementation does not depend solely on the program itself, but on understanding and cooperation from all parties involved.

Although the questionnaire and interview findings showed that teachers were welcoming notions of cultural elements and values, the document analyses and observation findings revealed that neither cultural elements nor values were adequately reflected in classroom materials and course books. Naming one unit as "friendship", or incorporating Turkish private names into activities but concentrating on structural and linguistic elements in classes will only serve for perception management on paper rather than lead to a real change in the classes. As Kırkgöz, Çelik and Arıkan stated (2016), designing classroom texts and other teaching tools, materials designers must ensure that these resources can effectively serve as bridges between the program and the actual teaching context; and classroom teachers, with support from school administrators, must take an active stance in applying the suggested activities in the classroom.

While the questionnaire and interview findings showed that teachers found alternative assessment techniques useful and appropriate, in-class observations displayed that assessments were based on tests or quizzes comprising multiple choice and fill-in-the-blanks questions, or matching tasks. In the interviews, teachers highlighted that they mostly used multiple choice type assessments with eighth graders, since it is the type to most likely be used in the national high-stake examination to be taken by all students at the end of the eighth grade. In addition, as families reportedly wanted their children to enroll into better high schools via higher scores in the national examination, they urged the teachers prepare students for this exam rather than focusing on communicative methodologies and activities that 
they perceived "game-like and childish". While such concerns were raised for eighth graders, classroom observations revealed that the case is not different at other class levels. For all levels, it was observed that assessment techniques, such as fill in the blanks, multiple choice or matching were commonly used. Thus, it is evident that structural and linguistic functions of language, rather than communicative competence, are being emphasized. Echoing Mickan (2013), an important problem in foreign language teaching is that assessment methods and techniques offered in the curricula, and the ones used during high stakes national examinations, which focus on grammatical accuracy and vocabulary knowledge, do not match. As Coleman noted (2009), prior to the national examination, both teachers and students concentrate on the exam content and, thus, the teaching-learning process turns exam driven. The present study finds support from the study of Özsevik (2010) who remarked that the main hindrance to the use of CLT in Turkey appears to be the grammar-based examination system. The researcher stated that the successful integration of CLT into English teaching in Turkey will only be possible if the examination system is amended in a way that will give the development of communicative skills the importance that it deserves.

The questionnaire results indicate that teachers mostly consider the given class hours inadequate. Numerous teachers stated that three hours for the fifth and sixth grades, and four hours for the seventh and eighth grades are not adequate, and within this period, it is impossible to cover all the objectives stated in the curriculum. The interviewed teachers also stated the same inadequacies for the sixth, seventh, and eighth grades. These findings are in line with the findings of Aksoy, Bozdoğan, Akbaş and Seferoğlu (2018). Kandemir (2016) similarly stated that teachers found class hours inadequate.

Another salient finding of the present study is the lack of in-service training offered to English language teachers. Only eight teachers among the 96 answering the questionnaire, and one among seven of the interviewees stated that they got in-service training on the updated curriculum or contemporary teaching methodologies. It is clear that an updated curriculum brings with it new approaches, methodologies and assessment techniques. In this case, teachers who are assigned to enact the updated curriculum, require in-service training based on all the updates. Although the interviewed teachers stated that the newly recruited teachers need such in-service programs, classroom observations revealed that all English language teachers need to upgrade themselves in terms of the updated curriculum. As stated by the interviewed teachers, these trainings need to be in the form of workshops, to be delivered in real class cases. Echoing Aksoy (2019), such in-service training programs need to be practice-oriented and continuous. Within this context, it is clear that English language teachers need training on how to use the communicative approach effectively in their classes.

The present study is supported by previous studies dealing with the theory-practice link stating that curriculum reforms or updates stay on the paper but are not transferred to in-class practices (Butler, 2011; Fitzpatrick, 2011; Kırgköz, 2008). The results of the present study also support the findings of Erarslan (2019), who found that curricula changes in Turkey, related to primary school English language teaching programs, fall short of meeting the demands of the country and global world in terms of equipping learners with the necessary communicative skills in English. The researcher concluded that class hours are limited for teachers to cover the program content, exerting undue pressure on the part of the teachers and suggested that the factors which hamper the process of language teaching and learning in a negative way have to be handled and addressed carefully by the decision makers, program developers and other agents, such as education planners.

It seems impossible to reflect the desired philosophy of any curriculum, unless teachers internalize that philosophy and become proficient users of the methodologies required by the curriculum. Thus, it is critical that teachers get support in form of in-service training on how to actualize the curriculum updates. 


\section{CONCLUSION}

Resorting to Stake (1967), the present study found that there is a lack of congruence and contingency among the intended and observed transactions within the scope of the updated secondary school curriculum. Considering that there is a remarkable gap between what is intended and what is carried out, first, a national foreign language policy document should be prepared, and a unique foreign languageteaching system for the needs and realities of Turkey should be targeted. Second, the updated English language curriculum needs to be evaluated countrywide. In addition, it is evident that English language teachers need in-service training on the use of the communicative approach as well as technology use and authentic materials preparation. This can be achieved by a large-scale protocol establishment between MoNE and a couple of universities who excel in teacher training. On the other hand, MoNE needs to be supported in terms of writing better and more effective course books. In addition, the intensive English education at some fifth-grade levels need to be disseminated, and English instruction should be further extended and incorporated into the sixth, seventh and eighth grades. Finally, if the national examination at the end of eighth grade continues, then the grading/scoring of the English section needs to be equalized with that of the math or science sections, and a variety of question types, including alternative assessment methods, needs to be established.

\section{Limitations}

The findings of this study are limited to data gathered from 96 English language teachers who participated in answering the questionnaire, seven English language teachers who were interviewed, and four classroom observations at different secondary school levels. Thus, the findings cannot be easily generalized to the whole population. However, it is believed that this study has detected critical aspects that impede a more fully implementation of the prescribed EFL curriculum for secondary schools in Turkey. Further studies will contribute to a deeper understanding of the gap between theory as expressed in curricular documents, teachers' views on curricular changes and realized practices.

\section{Acknowledgements}

Ethical consent for this study was obtained from TED University Ethical Committee, No: 27535802020/, Date: 09.05.2019 and from the Provincial Directorate of National Education-Ankara, No: 14588481-605.99-E.7723497, Date: 16.04.2019.

\section{REFERENCES}

Ağçam, R., \& Babanoğlu, M.P. (2018). The solo analysis of EFL teaching programs: Evidence from Turkey. Turkish Studies-Educational Sciences, 13 (27), 1-18. DOI: 10.7827/TurkishStudies.14255

Aksoy, E., Bozdoğan, D., Akbaş, U., \& Seferoğlu, G. (2018). Old wine in a new bottle: Implementation of intensive language program in the 5th grade in Turkey. Eurasian Journal of Applied Linguistics 4(2), 301324. DOI: $10.32601 /$ ejal.464187

Aksoy, E. (2019). Developing a modular in-service training program to improve teaching skills of primary school teachers of English in Turkey. International Journal of Curriculum and Instruction, 1(1), 141-171.

Butler, Y. G. (2011). The implementation of communicative and task-based language teaching in the Asia-Pacific Region. Annual Review of Applied Linguistics, 31, 36-57. DOI: 10.1017/S0267190511000122

Büyükduman, F.İ. (2005). The opinions of elementary school English teachers on the English curriculum for elementary schools. Hacettepe University Journal of Education, 28, 55-64.

Carless, R. D. (2004). Issues in teachers' reinterpretation of a task-based innovation in primary schools. TESOL Quarterly, 38(4), 639-662. DOI: 10.2307/3588283 
Cheserek, G. J., \& Mugalavi, V. K. (2012). Challenges and reforms facing Kenyan education system in the $21 \mathrm{st}$ century: Integrating the principles of vision 2030 and constitution 2010. Journal of Emerging Trends in Educational Research and Policy Studies, 3(4), 471-478.

Coleman, H. (2009). Indonesia's 'international standard schools': What are they for? Paper presented at the 8th Language and Development Conference, Dhaka, Bangladesh.

Coşkun, A. (2011). Investigation of the application of communicative language teaching in the English language classroom - a case study on teachers' attitudes in Turkey. Journal of Linguistics and Language Teaching, $2(1)$.

Daloğlu, A. (1996). A case study on evaluating the "certificate for overseas teachers of English" curriculum at Bilkent University. (Unpublished doctoral dissertation). Middle East Technical University

Demirlier, H. (2010). Students' and teachers' attitudes towards the newly developed curriculum of primary schools. (Unpublished master's dissertation). Muğla Sitkı Koçman University.

Denkci-Akkas, F., \& Coker, B. (2016). The use of communicative approach in 9th grade EFL classes. Eurasian Journal of Educational Research, 65, 71-90. DOI:10.14689/ejer.2016.65.05

Dinçer, B. (2013). Evaluation of 7th grade English language curriculum according to Stufflebeam's CIPP model. (Unpublished Doctoral dissertation). Adnan Menderes University.

Dinçer, B., \& Saracaloğlu, A.S. (2018). Evaluation of 7th grade English language curriculum based on Stufflebeam's CIPP model according to teachers' views. Turkish Studies-Educational Sciences, 13 (19), 561-588. DOI: 10.7827/TurkishStudies.14139

Er, K. O. (2006). Evaluation of English curricula in the $4^{\text {th }}$ and $5^{\text {th }}$ grade primary schools. Ankara University Journal of Faculty of Educational Sciences, 39, 1-25.

Erarslan, A. (2019). Factors affecting the implementation of primary school English language teaching programs in Turkey. The Journal of Language Teaching and Learning, 9(2), 7-22.

Erbakan G. (2001). Teachers opinions about primary schools' English program. (Unpublished master's dissertation). Hacettepe University.

Erbilen Sak, O. (2008). Evaluation of the English program for primary education according to teachers' opinions. (Unpublished master's dissertation). Bolu Abant İzzet Baysal University.

Erdem, S., \& Yücel Toy, B. (2017). Determination of the needs for foreign language oriented fifth grade English curriculum. Turkish Studies, 12 (28), 259-280. DOI: 10.7827/TurkishStudies.12346

Erdoğan, V. (2005). An evaluation of the English curriculum implemented at the 4th and 5th grade primary state schools: The views of the teachers and the students. (Unpublished master's dissertation). Mersin University.

Fitzpatrick, D. (2011). Making sense of the English language policy in Thailand: An exploration of teachers' practices and dispositions. (Unpublished doctoral dissertation). University of Exeter.

Fraenkel, J.R., Wallen, N. E., \& Hyun, H.H. (2012). How to design and evaluate research in education (8th edition). New York: McGraw-Hill.

Gözütok, D. (2001). Program değerlendirme [Program evaluation]. In Mehmet Gültekin (Ed.), Öğretimde planlama ve değerlendirme [Planning and evaluation in instruction] (p.p 175-190). Eskişehir: Anadolu Üniversitesi Yayınları.

Hamid, M. O., \& Honan, E. (2012). Communicative English in the primary classroom: Implications for Englishin-education policy and practice in Bangladesh. Language, Culture and Curriculum, 25(2), 139-156. DOI: 10.1080/07908318.2012.678854

Kandemir, A. (2016). An evaluation of 2nd grade English curriculum within a participant-oriented program evaluation approach. (Unpublished master's dissertation). Pamukkale University.

Karavas, E. (1993). English language teachers in the Greek secondary school: A study of their classroom practices and their attitudes towards methodological and materials innovation. (Unpublished doctoral dissertation). University of Warwick.

Kırkgöz, Y. (2008). A case study of teachers' implementation of curriculum innovation in English language teaching in Turkey primary education. Teaching and Teacher Education, 24(7), 1859-1875. DOI: 10.1016/j.tate.2008.02.007.

Kıkgöz, Y., Çelik, S., \& Arıkan, A. (2016). Laying the theoretical and practical foundations for a new elementary English curriculum in Turkey: a procedural analysis. Kastamonu Education Journal, 24 (3), 1199-1212.

Mickan, P. (2013). Language curriculum design and socialization. United Kingdom, UK: Multilingual Matters.

Miles, M. B., \& Huberman, M. A (1994). Qualitative data analysis: An expanded sourcebook. Thousand Oaks, CA: Sage.

MoNE (2013). Illkögrretim kurumları ingilizce dersi (2, 3, 4, 5, 6, 7 ve 8. sinıflar) ögretim programı [Primary and secondary school (grades 2-8) English language curriculum]. Talim ve Terbiye Kurulu Başkanlığ [Board of National Education]. Retrieved from https://dyned33.files.wordpress.com/2013/02/ingilizce_2-8.pdf on 15 May 2019.

MoNE (2018). Ingilizce dersi ögretim programı 2-8. [English language curriculum of grades 2-8]. T.C. Millî Eğitim Bakanlığı [Ministery of National Education]. Retrieved from 
http://mufredat.meb.gov.tr/Dosyalar/201812411191321-

\% $4 \%$ B0NG\%C4\%B0L\%C4\%B0ZCE\%20\%C3\%96\%C4\%9ERET\%C4\%B0M\%20PROGRAMI\%20K1 as\%C3\%B6r\%C3\%BC.pdf on 15 May 2019.

Illköğretim ve eğitim kanunu ile bazı kanunlarda değişiklik yapılmasına dair kanun [Primary Education Law] (2012). Official Gazzette (28261). Retrieved from https://www.resmigazete.gov.tr/eskiler/2012/04/20120411.htm on 15 May 2019.

Ornstein, A. C., \& Hunkins, F. P. (2016). Curriculum: Foundations, principles, and issues (7th edition). United Kingdom: Pearson Educational Leadership.

Ozsevik, Z. (2010). The use of communicative language teaching (CLT): Turkish EFL teachers' perceived difficulties in implementing CLT in Turkey. (Unpublished master's dissertation). University of Illinois at Urbana.

Stake, R. E. (1967). The countenance of educational evaluation. Retrieved from https://pdfs.semanticscholar.org/b07e/5b61cde550bfb0b64e895674a236c9003335.pdf on 15 May 2019.

Ültanır, G. (2003). Eğitimde planlama ve değerlendirmede kuram ve teknikler [Theories and techniques in educational planning and evaluation]. Ankara: Nobel Yayın Dağıtım.

Varış, F. (1997). Eğitimde program geliştirme [Curriculum development in education]. Ankara: Alkım Yayınevi.

Wang, H. (2006). An implementation study of the English as a foreign language curriculum policies in the Chinese tertiary context. (Unpublished doctoral dissertation). Queen's University, Belfast.

Yaacob, A. (2006). Malaysian literacy practices in English: 'Big books', CD-ROMs and the year 1 English hour. (Unpublished doctoral dissertation). University of Warwick.

Yüce, E. (2018). Evaluation of the high school 9th grade English language curriculum of Turkey in relation to the CEFR principles. (Unpublished doctoral dissertation). Hacettepe University.

Yücel, E., Dimici, K., Yıldız, B., \& Bümen, N. (2017). An analysis of the primary and secondary school English language curricula published over the last 15 years. Ege Journal of Education, 18 (2), 702-737. DOI: 10.12984/egeefd.305922 


\section{APPENDIX 1}

Table 9.

Observation form regarding grade levels

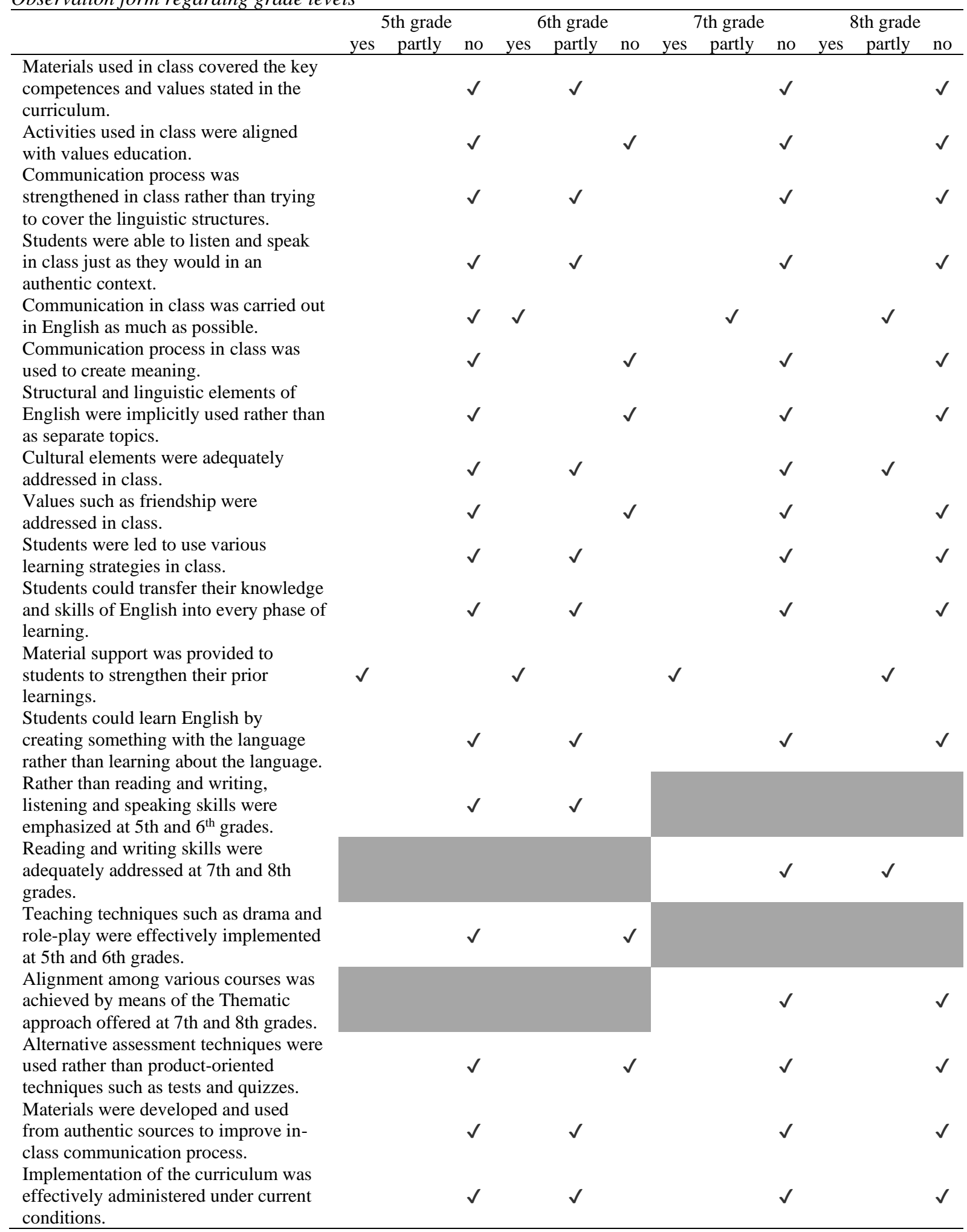




\section{TÜRKÇE GENIŞLETILMIŞ ÖZET}

Türkiye'de 2017 yılında diğer derslerin öğretim programı yanında İngilizce öğretim programları da güncellenmiştir. Güncelleme kapsamında Avrupa Ortak Diller Metni Çerçeve Programı kapsamında yabancı dilin özgün iletişimsel bağlamda kullanımının amaçlandığı ve özellikle arkadaşlık, dürüstlük, adalet, sabır vb. değerler ile kültürel ögelerin program içeriğine yansıtıldığı ifade edilmiştir. Programlarda değerlendirme yöntemleri olarak ise öğrencinin kendi kendini değerlendirdiği öz değerlendirme ve akran değerlendirme gibi yöntemlerin ön plana çıktığı görülmektedir (MoNE, 2018).

Güncellenen programların sistematik bir şekilde değerlendirilmesi programın sürekliliği açısından son derece önemlidir. Programın etkililiğinin değerlendirilmesi, program geliştirme sürecinin ilk adımlarındandır (Gözütok, 2001; Ültanır, 2003). Kâğı̆t üzerinde güncellenen programların hedeflediği yeterliklere ve uygulamadaki etkililiğine ilişkin veri toplamak ve programı bu yönüyle değerlendirmek ise kuram-uygulama bağını sağlamanın önemli bir yöntemi olarak ortaya çıkmaktadır. Bu bağlamda reform adı altında gerçekleştirilen birçok program güncelleme çalışmasının gerçek uygulamalara yansımadığı ve kâğıt üzerinde kaldığını gösteren çalışmalar bulunmaktadır (Wang, 2006; Cheserek ve Mugalavi, 2012).

Mevcut çalışma güncellenen ortaokul İngilizce öğretim programlarının gerçek uygulamalar ile olan ilişkisini göstermesi bakımından son derece önemlidir. Bu kapsamda mevcut araştırmada Stake (1967)'in uygunluk-olasılık modeli kullanılarak beklenen ve gözlenen özellikler arasındaki uyum araştırılmıştır. Bu kapsamda yanıt aranan sorular şu şekildedir:

1) Öğretmenlerin programın; kazanımlarına, içeriğine, öğrenme-öğretme sürecine, değerlendirme sürecine, uygulamalarının etkililiğine ilişkin görüşleri nelerdir?

\section{2) Güncellenen ortaokul İngilizce öğretim programının sınıf içi uygulamalara yansıması nasıldır?}

Bu kapsamda araştırmada 2017 yılında güncellenen ortaokul İngilizce öğretim programlarının karma araştırma kapsamında doküman analizi, görüşme, yapılandırılmış anket ve sınıf içi gözlemler şeklinde dört farklı veri toplama aracı kullanılarak değerlendirilmesi amaçlanmıştır. Anket verileri Türkiye'nin farklı illerinde çalışan 96 İngilizce öğretmeninden toplanmış, görüşmeler Ankara ilinde bir devlet ortaokulunda çalışmakta olan 7 İngilizce öğretmeni ile yapılmış, sınıf içi gözlemler ise aynı ortaokulda dört farklı sınıf düzeyinde gerçekleştirilmiştir. Anket için kartopu örnekleme yöntemi, görüşmeler ve gözlemler için ise amaçlı örnekleme yöntemi benimsenmiştir. Araştırmada veri çeşitliliği sağlamak adına üçgenleme tekniği kullanılmıştır.

Araştırma kapsamında kullanılan ilk veri toplama aracı doküman analizidir. Bu kapsamda 2017 yılında güncellenen ortaokul İngilizce öğretim programı temel doküman olarak kullanılmıştır. Bununla birlikte örnek ders planları ve kullanılan materyaller de dokümanlar olarak incelenmiştir. Diğer veri toplama aracı olan yapılandırılmış anket iki bölümden oluşmuş ve ilk bölümde demografik bilgiler ikinci bölümde ise öğretmenlerin programın temel bileşenlerine ilişkin görüşlerini almak amacıyla yapılandırılmış ifadeler kullanılmıştır. Bu ifadelere öğretmenlerin evet, kısmen, hayır şeklinde yanıt vermeleri, hayır ve kısmen seçeneklerini işaretlemeleri durumunda ise bu durumun nedenlerini yazmaları istenmiştir. Yapılandırılmış görüşmeler üçüncü veri toplama aracını oluşturmaktadır. $\mathrm{Bu}$ kapsamda yapılandırılmış olan 11 soru 7 İngilizce öğretmenine yönlendirilmiş ve yaklaşık 30 dakika içinde sorulara yanıt vermeleri beklenmiştir. Öğretmenlerin anadilleri Türkçe olduğu için görüşme süreci Türkçe gerçekleştirilmiştir. Son veri toplama aracı olan gözlem formu ise güncellenen programda amaçlanan temel özellikler dikkate alınarak 20 madde şeklinde hazırlanmıştır. Gözlenmesi beklenen özellikler evet, kısmen ve hayır şeklinde kategorize edilmiş ve gözleme ilişkin detaylı not almak amacıyla her bir maddenin yanına açıklama bölümleri eklenmiştir. Gözlemler her bir sınıf düzeyinde 
(5-6-7-8) birer saat olarak gerçekleştirilmiştir. Veri toplama sürecine ilişkin olarak gerekli izinler öncelikle Ankara İl Milli Eğitim Müdürlüğünden akabinde ise TED Üniversitesi İnsan Araştırmaları Etik Kurulundan alınmıştır.

Anket sonuçları öğretmenlerin güncellenen programın kazanımlar, içerik, öğrenme-öğretme süreci, değerlendirme ve sınıf içi uygulama boyutlarına ilişkin olumlu görüşlere sahip olduklarını göstermiştir. Programda iletişimsel yaklaşıma ve uygulamalara vurgu yapılmış olması, kültürel ögelere ve değerlere yer verilmiş olması öğretmenler tarafından memnuniyetle karşılanmıştır. Öğretmenler ayrıca etkileşimli öğretim yöntemleri ve alternatif ölçme-değerlendirme yaklaşımları konularında da olumlu görüş belirtmişlerdir. Görüşme yapılan öğretmenler de güncellenen programlar ile birlikte sınıflarında iletişim sürecinin daha yoğun vurgulandığını ve tematik yapılanmayı olumlu bulduklarını ifade etmişlerdir. Ayrıca EBA platformunu daha yoğun ve etkili olarak kullandıklarını ve okullarında uygulanan yabancı dil ağırlıklı program sayesinde iletişim sürecini güçlendirmek adına daha fazla zaman bulduklarını ifade etmişlerdir. Gerek anket gerekse görüşme bulguları öğretmenlerin iletişimsel yaklaşıma karşı olumlu bakışa sahip olduklarını ve bunu sınıflarına yansıtmaya çalıştıklarını göstermesi bakımından önemlidir. Bununla birlikte sınıf içi gözlemler programda amaçlanan iletişimsel yaklaşım uygulamalarının sınıf içi etkinliklere yeterince yansıtılmadığını ve sınıf içi iletişimin yabancı dil ile anlam oluşturmaktan çok dilbilgisi yapılarına odaklandığını göstermiştir. İletişim sürecinin çoğunlukla öğretmenden öğrenciye tek yönlü gerçekleştiği ve drama, rol oynama gibi iletişimsel tekniklerin yeterince kullanılmadığı da görülmüştür. $\mathrm{Bu}$ kapsamda araştırma bulguları alan yazındaki önemli birkaç araştırma bulgusunu destekler niteliktedir. Kırkgöz (2008) yaptığ çalışmada öğretmenlerin iletişimsel yaklaşım temelli etkinlikleri içselleştiremediğini, öğrencilerin ise çoğu öğretmen merkezli olan etkinliklere yeterince katılmadığını ifade etmiştir. Mevcut araştırmada da benzer şekilde öğretmenlerin yabancı dili anlam ve bağlam oluşturma amacı yerine dilin yapısal özellikleri üzerinde durdukları ve iletişim boyutunun büyük oranda göz ardı edildiği görülmüştür. Karavas (1993)'ın da işaret ettiği gibi iletişimsel yaklaşım sınıf içi etkinlik boyutunda gerçek uygulamalara yeterince yansımamış ve kuramsal düzlemde kalmıştır.

Diğer yandan gözlem yapılan sınıflarda etkinlikler ile temaların ve değerlerin yeterince ilişkilendirilmediği de görülmüştür. Programda belirtilen arkadaşlık, dürüstlük, adalet vb. değerlerin sınıf içi etkinliklerde herhangi bir yansıması gözlenmemiştir. Anket bulguları öğretmenlerin değerler konusunda ders kitapları ve materyallerindeki eksikliğe vurgu yaptıklarını göstermektedir. Bununla birlikte sınıf içi uygulama boyutunda öğretmenlerin ders kitabına bağlı kalmaları ve dilin yapısal özelliklerine vurgu yapmaları neticesinde değerlerin göz ardı edildiği ve uygulamalara yeterince yansımadığı söylenebilir. Ünitelerin temas bağlamında sunulmasının da benzer şekilde kâğıt üzerinde kaldığ 1 ve yalnızca ünite adları ile ünite içerisinde geçen özel isimlerde vurgulandığı görülmüştür. Gerek tema yapılanması gerekse programda vurgulanan değerlerin uygulamaya yansitılamaması daha kapsamlı olarak yapılacak başkaca çalışmalarda ele alınabilir. Diğer yandan gerek anket gerekse görüşme bulguları programlarda vurgulanan alternatif ölçme-değerlendirme yaklaşımlarını ögretmenlerin faydalı ve gerekli bulduklarını göstermiştir. Bununla birlikte sınıf içi uygulamalara bakıldığında çoktan seçmeli, boşluk doldurmalı, eşleştirmeli soru türlerinin yoğun bir şekilde kullanıldığ 1 gözlenmiştir. Özellikle 8. sınıf düzeyinde öğrencilerin yılsonunda girecekleri ulusal çoktan seçmeli sınav dolayısıyla öğretmenlerin de standart çoktan seçmeli soru türünü kullanmak durumunda kaldıkları ifade edilmiştir. Bununla birlikte yapılan gözlemlerde diğer sınıf düzeylerinde de durumun farklı olmadığı ve çoktan seçmeli soru türünün yoğun bir şekilde benimsendiği görülmüştür. $\mathrm{Bu}$ kapsamda Mickan (2013)'in da belirttiği gibi yabancı dil öğretimi sürecinde programlarda tanımlanan ölçme değerlendirme yöntem ve teknikleri ile ulusal çaplı sinavlarda sorulan soru türlerinin uyumsuzluğu önemli bir problem olarak göze çarpmaktadır.

Neticede anket ve görüşme sonuçları öğretmenlerin bakış açısıyla güncellenen programların uygun ve etkili olduğunu göstermekle birlikte, sınıf içi gözlemler kuram-uygulama bağını gerçekleştirmede kat edilmesi gereken bir hayli mesafe olduğunu göstermektedir. Dolayısıyla amaçlanan ile yapılabilen arasında önemli bir fark mevcut ise öncelikle bir İngilizce dil politika belgesi hazırlanması ve bu doğrultuda özgün bir yabancı dil öğretim ekosistemi amaçlanması gerekmektedirr. 